\title{
$\mathrm{D}) \mathrm{M}$ \\ Volume 7 - Fall 2011 \\ djim.management.dal.ca
}

\section{Rediscovering the Steady State of Classical Economics: A Discussion on the Origin of the Economic Theory of Sustainability}

\begin{abstract}
Limits on economic growth are not new concepts; rather they originated with the earliest thinkers on the philosophy of economics. Adam Smith, and others of his generation, wrote about stationary economies and uneconomic growth centuries before modern thinkers rediscovered these issues. Classical economic theorists offer insight into modern concerns about economic growth. If societies choose a sustainable human enterprise, then using an interdisciplinary approach may create mechanisms that allocate our scarce resources more efficiently and increase real prosperity today and tomorrow.
\end{abstract}

\footnotetext{
About the Author(s): Chris Whynacht is a special status graduate student in the School of Resource and Environmental Studies at Dalhousie University. Chris completed a BA in Political Science in 1996 at Dalhousie and has since worked in business development and general management consulting. Chris's practice is focused on sustainable community based economic development, and he does not believe that growth always equals prosperity. Though focused on local communities, Chris has served on Team Canada Trade Missions to the US. $\mathrm{He}$ is an avid sailor, outdoor enthusiast, and Chairperson of the Dalhousie Association of Graduate Students.
} 


\section{Rediscovering the Steady State of Classical Economics: A Discussion on the Origin of the Economic Theory of Sustainability}

This discussion paper explores the writings of Adam Smith and other classical economic authors to determine what insights they about sustainability. The main tenet of modern steady state economic theory, as described by Herman Daly (1973), is that the human enterprise needs to be sustainable within the biosphere. However, Daly did not draw upon Smith's work as a starting point in his analysis, but rather took a more ecological approach. The rationale for a sustainable human enterprise is clear to many ecologically-minded researchers today. Since all resources we humans consume and all of the wastes we produce come from and ultimately return to the biosphere, the human enterprise is bound by the dimensions of the biosphere (Dilworth, 2010). This concept that economies are ultimately limited by the environment is not new, but rather was critically important in early writings on the subject of economics. The classical understanding of these limits gave rise to the common dictum that economists are focused on studying the allocation of scarce resources.

If steady state economic theory can mature by being updated and reintegrated with classical economic thought and terminology, it may become more widely accepted as a framework to be used by both government and society at large in making sustainable policy decisions regarding economic development, environmental degradation, and sustainable economic growth.

Perhaps this integration could lead to the development of a new economic terminology-a language of sustainable economics that draws from the best of economic theory combined with an understanding of the natural world in which our human enterprise occurs.

Before proceeding with a discussion of this type, some clarification of terms is required. Growth, unless otherwise stated, refers to economic growth as measured by GDP analysis. Unless otherwise specified, limits on GDP growth are from external sources, such that additional inputs cannot be supplied from traditional stocks in order to increase production. The productive output of industry and individuals may continue to improve via the process of innovation in any limited economy. As well, the society's prosperity may improve over time, although the prosperity of individuals may vary in relation to each other. The term prosperity is 
used here to describe the scale of an individual or nation's real wealth when measured comprehensively.

A limited economy does not in itself guarantee a sustainable human enterprise. Sustainability is a nebulous concept. However, I would suggest that, at minimum, a sustainable society harvests renewable resources at replenishable rates, so that it does not draw down on natural capital and adaptively manages finite resources over time to stimulate innovation as well as provide reasonably steady supplies of economic inputs and benefits. A sustainable society would also prevent the wastes and side effects of production and population from causing undue harm to the environment and thereby prevent a reduction in the society's overall carrying capacity. Reducing carrying capacity or natural capital results in decreased flows of environmental goods and services, which lowers overall production. Short term economic growth that lowers the long term productive capacity of a society is termed uneconomic growth.

Readers may be surprised to learn that Adam Smith, the founder of classical economic theory, believed in economic limits, and that he wrote about modern concepts such as carrying capacity and uneconomic growth. This could be a result of many individuals referencing his work out of context and citing that work to support an unregulated and unlimited growth model for the human enterprise. However, it is Smith who states in An Inquiry into the Nature and Causes of the Wealth of Nations (The Wealth) that "labourers, and those who do not labour at all, are all equally maintained by the annual produce of the land and labour of the country. This produce, how great soever, can never be infinite, but must have certain limits" (Smith, 1863 p.136).

Why do we tend to overlook insights from classical economists on subjects of current interest, such as sustainability? One reason, which I will discuss later, is that the elaborate style authors in Smith's era used does not allow for modern speed readers to comfortably skim volumes of considerable length and breadth. Hollander gives another explanation of why modern readers do not revisit these classic works in the preface of The Economics of Thomas Robert Malthus, when he points out that, "there is also a sophisticated form of anachronism that entails denying the presence in an early writer's work of modern concepts merely because they are expressed differently." (Hollander, 1997, p. xiv). 
Before delving further into the work of Smith, it is important to briefly discuss the society in which he and his contemporaries lived and wrote. Europe in the late 1700s was ruled by kings and courts and was very religious and predominantly Christian. This historical period is referred to as the Enlightenment, and it produced revolutions in philosophy brought about by changes in longstanding political and economic structures as democracy emerged as the dominant political theory (Cameron, 1997). As well, what Smith characterized as the mercantile period was reaching its conclusion, and new ideas about economics and nationalism were developing.

Smith was born in a small fishing village and rose to become a seminal thinker in the Scottish Enlightenment (Heilbroner, 1986). Smith incorporated many ideals of the Enlightenment era into his work. Published in 1776, The Wealth is his last major volume, and the one he is best known for today. It is important to note that Smith thought of himself foremost as a moral philosopher, and he wrote on a wide variety of subjects before turning his focus to what he termed "political economy" - now known as economics.

One of Smith's earliest works was a history of astronomy that explained the physical laws of the universe as they were understood from early times up to what Smith termed "the modern thinking of Newton" (Heilbroner, 1986). It is important in our discussion of limited economies to note that Smith was well aware of the enormous size of the cosmos and understood the earth within that context. In this, his thinking anticipates the reaction to the picture known as 'Earth Rise' which sparked the environmental movement in the 1970s by showing how small and fragile our biosphere really is (Gore 2006, pp.12-13). Smith's deep understanding of cosmology and astrophysics may have influenced his belief that infinite growth of the human enterprise is impossible. His understanding of the scale of the universe and gravity's role in keeping order may have instigated his search for a phenomenon that provided similar social order here on Earth (Heilbroner, 1986). This concept he later termed the invisible hand, and in it he saw a mechanism that was created by God (Smith was a very devout Christian) and operated like gravity that to provide order. The concept of the invisible hand, despite the vast number of times it has been cited by economists, appears only once in The Wealth. 
Seldom noted is that the sole passage in The Wealth that includes the term "Invisible Hand" (Smith, 1863, p. 184) comes in Book IV, Chapter II, titled "Of Restraints upon the Importation from foreign Countries of such Goods as can be produced at Home" (pp. 183-191). Rather than promoting free trade and globalization, Smith thought the invisible hand would promote the purchase of goods made closer to home. The rationale for this belief is well described in another of Smith's works, The Theory of Moral Sentiments (The Sentiments), and is the mechanism Smith felt his deity provided mankind in order to maintain morality and social order (Smith, 1976). The invisible hand concept is much more prevalent in The Sentiments, appearing numerous times. This was a document which Smith was proud of and revised on at least six occasions up until 1790, very close to his death (Heilbroner, 1986).

Whether or not Smith's full range of opinions are valid with regard to his theory of the invisible hand, it is vital to know Smith's view point in order to best understand this mechanism. Smith did not see his conceptual hand as promoting greed or avarice, but rather believed that the basic decency and manners of a society as a whole would make up for the misbehaviour of those too focused on profit or personal greed (Heilbroner, 1986). Smith was apt to use physiological metaphors and was aware that when parts of the body grow out of proportion, there is likely to be a negative effect to the whole system, even though the parts themselves are vital (Reill, 2010). In Smith's eyes, true self-interest is maintained not through excessive consumption, but rather by living in a moral fashion. In this way, one may obtain the respect of God and fellow citizens, and this respect is more valuable than pure personal earthly profit (Smith, 1976).

One can imagine that as Smith only briefly mentions the invisible hand once in The Wealth, he must assume readers were already familiar with the concept from his earlier works. In his time, they were. The Sentiments was a very popular book with multiple editions printed in many languages, and it helped launch Smith into a degree of fame. Today, very few people other than scholars read or remember this publication, yet The Sentiments is critical to understanding the mindset of Adam Smith and the basis for his theories about economics (Heilbroner, 1986). The lack of a modern readership of Smith's work is something to be regretted, for by examining the scope of his writing, one is able to gain a much richer appreciation of his ideas and admonishments. The same is true of all the classical theorists in 
economics, many of whom were very prolific correspondents with thousands of pages of documents on record.

As mentioned earlier, part of the reason that Smith and other classical writers are not widely read anymore is the convoluted style used by authors in the 18th century. A sample from Smith's The Wealth may better illustrate this point:

I shall endeavor to explain, as fully and distinctly as I can, those three subjects in the three following chapters, for which I must very earnestly entreat both the patience and attention of the reader: his patience in order to examine a detail which may perhaps in some places appear unnecessarily tedious; and his attention in order to understand what may, perhaps, after the fullest explication which I am capable of giving of it, appear still in some degree obscure. I am always willing to run some hazard of being tedious in order to be sure that I am perspicuous; and after taking the utmost pains that I can be perspicuous, some obscurity may still appear to remain upon a subject in its own nature extremely abstracted (Smith, 1863, p. 12).

Smith is best read aloud, as this captures the style and substance of his era and gives the reader time to appreciate his thoughts. Many of Smith's early writings are based on lectures he gave as a professor at Glasgow University, and they read best if one does not skim, but rather savours each paragraph (Heilbroner, R., 1986). Smith and his contemporaries are impossible to speed read, even if one is familiar with the writing of the era. Due in part to his complicated prose, Smith's words are often taken out of context and used to support opinions that are contrary to his own. Even a brief but fulsome reading of Smith shows that he was neither a supporter of unregulated free trade nor unlimited consumption, but rather felt that prudence, supporting local industry, and saving were critical to a nation's real wealth or a citizen's prosperity.

Critical to our discussion on classical support for sustainable economics are Smith's comments with regard to the components of prices. Smith felt that prices were composed of three elements: labour, rent, and profit. He went on to state in this farming example that:

These three parts seem either immediately or ultimately to make up the whole price of corn. A fourth part, it may perhaps be thought, is necessary for replacing the stock of 
the farmer, or for compensating the wear and tear of his labouring cattle, and other instruments of husbandry. But it must be considered that the price of any instrument of husbandry, such as a labouring horse, is itself made up of the same three parts...." (Smith, 1863, p. 21)

This passage shows that for Smith, replenishment of capital used in production was a main component of prices, but was included in his three core components. This is supported by Smith's belief that in a fully employed economy, wages and profits would be low-presumably due to rent being a larger component of the final price.

Rent, Smith believed, was the component of prices that was primarily responsible for the upkeep and maintenance required for the land (ecosystem) to maintain productivity. Today a common mantra in Western society is that a fully-employed economy will lead to higher wages and profits, as preached by most politicians who advocate for growth as a solution to economic crises. Smith disagreed. His belief was that:

In a country which had acquired that full complement of riches which the nature of its soil and climate, and its situation with respect to other countries allowed it to acquire; which could, therefore, advance no further, and which was not going backwards, both the wages of labour and the profits of stock would probably be very low (Smith, 1863, p. 39).

The focus of our modern day financial markets on short term profit allows firms to abrogate required rent expenses, which reduces replenishment after production and draws down on capital stocks over time. Smith did not use the term uneconomic, but he did argue that in some conditions bringing products to market may pay profit but leave insufficient revenue for rent, thus drawing down on capital (Heilbroner, 1986). This situation of paying profit but not rent does not create wealth but is, in fact, the antithesis of it. Smith himself anticipated that this may occur and lectured in many passages about the need to understand and honour the components of prices, also acknowledging that the components of price could be confused. This point is clearly made in chapter notes in The Essential Adam Smith, when Heilbroner states: 
They [the components of price] are sometimes confounded; for example, a gentleman farmer's rent is called profit, a common farmer's wages are called profit, and so are an independent manufacturer's wages, while the rent and profit of a gardener cultivating his own land are considered earnings of labour (Heilbroner, 1986, p. 185).

In general, Smith was optimistic about the coming age he foresaw, but he was also very cautionary in his writing and presented many restrictions and warnings. Smith saw a role for the state in supporting and also regulating the economy. Specifically, in The Wealth and also in his Lectures on Jurisprudence, we see Smith remarking on the role of government to ensure cheapness and plenty for such basic necessities as clean water while also ensuring tidiness of the surroundings (Smith, 1978). Smith's 18th-century concept of tidiness included keeping streets clean from waste, an early form of environmental and public health safeguard. However, he felt that this subject was not worthy of his insights, stating that these issues are "... of too mean a nature, tho [sic] no doubt of considerable importance, to be the subject of a lecture" (Smith, 1978, p. 44).

Ultimately, Smith believed that frugality increased wealth, and he would most likely not sanction policies that draw down savings in order to consume more frivolously and so grow the economy unsustainably. Smith understood that regardless of the demand from consumers, there would be no marketplace without producers, and that issues of production are paramount in economic analysis (Vermeij, 2004). Smith would never have supported the globalization of international capital markets or the drawing down of global stocks of natural capital without replenishing them through rental expenses before paying profits. He may not have used the term "unsustainable consumption," but Smith's desire to live a life without shame is not compatible with many unsustainable and modern practices (Jackson, 2006).

Though we have focused on him to this point, Smith was not alone in his thinking that infinite economic growth was impossible; many others who theorized about economics in the 18th and 19th centuries held similar beliefs. Again, many of these authors are often not read as fully as they could be by modern scholars of economics due to stylistic reasons. Some modern scholars have tried to place $18^{\text {th }}$-century authors in better context for readers by using more modern terminology. An example of this is Hollander's chapter entitled "Sustainable Growth: Accumulation and the aggregate-demand problem" in The Economics of Thomas Robert 
Malthus (pp. 505-585). This chapter points out Malthus's concerns regarding excessive accumulation, for while Malthus himself did not use the term "steady state economy," he did often comment on the concepts of stationary economies and populations.

Hollander contends that Malthus believed there were "several sources of premature deceleration and ultimate stationariness [sic]" (Hollander, 1997, p. 177). Malthus thought economies were capable of growth and stagnation, as well as a middle point that he described as stationary. Similarly, John S. Mill often used the term stationary when describing the economic state to be found at the end of the growth stage. Mill believed that society (or economy) would progress into an ultimately stationary state (Mill as reproduced in Ashley, 1909).

Although David Ricardo was often critical of his contemporary Malthus, he too describes the need for maintenance of productive land and machines and discusses the difficulty in tracking these expenses in final costs, as the following passage indicates:

If fixed capital be not of a durable nature, it will require a great quantity of labour annually to keep it in it's original state of efficiency; but the labour so bestowed may be considered as really expended on the commodity manufactured, which must bear a value in proportion to such labour (Ricardo as reproduced in McCulloch, 1881, pp. 2526).

In this single sentence, we see that Ricardo also believes that capital cannot be exploited without eventually requiring upkeep to maintain production, and that the expense of this upkeep should be embodied in the final price of the produce. The classical literature of economic theory is not always in complete agreement, and certainly requires a broader venue for a more fulsome discussion. However, it is clear that many of the earliest authors discuss some maximum or mature stage of economic activity as well a need to replenish the sources and machines of production.

One reason that Smith and his contemporaries felt that economies were limited was that populations were limited-thus there was a finite supply of labour. Malthus is perhaps best known for his Essay on Population in which he argued that populations cannot grow beyond the carrying capacity of the environment (Hollander, 1997). The result of a non-expanding 
population and a lack of additional resource inputs is that the economy becomes stationary until some innovation occurs which allows for a commensurate increase in production. A fullyemployed economy can thus grow arithmetically but not exponentially, such that, any advancement made would create a new ceiling beyond which further production is not possible.

This classical understanding of the intertwined nature of economic and ecological limits has not been understood by many readers over the years. This is obvious if one reads $20^{\text {th }}$-century theorists such as Julian Simon who forecasts population growth for seven billion years in his economic predictions (Simon, 1995). Simon clearly did concur with Smith's opinion that infinite population growth was impossible no matter how great the production of an economy. A simple critique of Simon is found in Jared Diamond's Collapse: How societies choose to fail or succeed. Diamond easily refutes Simon's claims about human growth and resource opportunities by observing that at the current rate of population growth, in less than 2000 years the mass of humans will equal the mass of the earth, while in 6000 years the mass of the human population will equal that of the universe (Diamond, 2005).

Economists can be excused for not understanding biophysical realities as fully as ecologists and vice versa. Many researchers in both fields are primarily focused on their specific research interests and are not always well informed about other, possibly related, disciplines. However, classical authors were not of this pattern-they were interdisciplinary, possessing varied interests and fields of study which they drew upon to understand and explain the world around them. However the break occurred, the result was that some economists lost touch with the realities of the finite world the human enterprise operates within. Yet these biophysical realities should be of more interest for they are the cause of the scarce resources whose allocation economists try to optimize.

The underpinnings for the argument that the economy must be a subset of the biosphere are clear and logical (Daly, 1996). Humans are just one of many species on this planet and we are subject to the same ecological processes as any other (Diamond, 1991). Ultimately, valid, peer-reviewed research is making it clear to most people that even humans have limiting factors which influence our population's ability to grow infinitely and that our footprint is growing larger (Rees, 1996). 
This is not to say that we as humans are unable to maximize our prosperity as a society within safe ecological limits. Rather, this is exactly the process we should be engaged in, as opposed to following policies that create uneconomic growth (Daly, 1996). If we do not take action to limit our economy to a sustainable level, then ultimately nature will assist us in decreasing the size of our human enterprise. My research leads me to believe that the process of making our economy sustainable is better undertaken voluntarily.

In order for our modern economy to develop a sustainable trajectory, we must adopt a more interdisciplinary approach. Rediscovering the work of classical economists may help integrate learning from the fields of ecology and economics, which could result in a new and deeper understanding of what makes a society prosper.

This synthesis of disciplines could lead to better models and measurements of the impacts of economic activity, both positive and negative. The work done by The Stockholm Resilience Center to quantify nine planetary boundaries for sustainable human activity may serve as a framework to gauge the success of our global enterprise (Rockstrom, et al., 2009). This should inspire economists to continue developing social support for measurements of economic activity and efficiency that accurately reflect progress and development as more than increasing per capita GDP. Although these measurements may incorporate income, they will also include demographic and social data (such as education, life expectancy and child mortality) so that accurate statements about a nation's prosperity can be made (Rosling, 2009).

If there are quantified ecological boundaries to sustainable human activity, then economists need to assist policy makers by informing them how to best achieve real gains in prosperity for all global citizens, whether they live in an OECD nation or one termed developing. There are many market-driven and regulatory mechanisms available to policy makers. Deciding which methods are optimal for any given nation or society is an undertaking that should excite economists and anyone interested in such issues.

Moving forward, I would suggest that our global priority should be to make constructive and positive changes so that the human enterprise becomes more sustainable, prosperous and resilient in the future. Increased awareness needs to be converted into ecologically informed 
policy initiatives that have broad support. The study of economics should become increasingly interdisciplinary to incorporate more biophysical context from the ecosphere we inhabit. This integration of knowledge from various disciplines could generate better welfare and higher levels of prosperity. For those interested and engaged in the topic of sustainable economics, I highly recommend revisiting the work of classical authors. Adam Smith and other authors of his generation offer fresher solutions than many would imagine, and insight into issues that are of great interest to us today. 


\section{References}

Cameron, R. (1997). A concise economic history of the world: from Paleolithic times to the present. New York: Oxford University Press.

Daly, H. E. (Ed.). (1973). Toward a steady-state economy. San Francisco: W.H. Freeman.

Daly, H. E. (1996). Beyond growth: The economics of sustainable development. Boston: Beacon Press.

Diamond, J. (1991). The rise and fall of the third chimpanzee. London: Radius.

Diamond, J. (2005). Collapse: How societies choose to fail or succeed. London: Penguin.

Dilworth, C. (2010). Too smart for our own good: The ecological predicament of humankind. New York: Cambridge University Press.

Gore, A., (2006). An inconvenient truth: The crisis of global warming. New York: Penguin Group.

Heilbroner, R. (1986). The essential Adam Smith. New York: W. W. Norton \& Company.

Hollander, S. (1997). The economics of Thomas Robert Malthus. Toronto: University of Toronto Press.

Jackson, T. (Ed.). (2006). The Earthscan reader in sustainable consumption. London: Earthscan.

McCulloch, J. R. (1881). The works of David Ricardo with notice of the life and writings of the author. London: John Murray.

Mill, J. S. (1909). Principles of political economy with some of their applications to social philosophy. library of economics and liberty. Retrieved from:

http://www.econlib.org/library/Mill/mIP61.html on December 12, 2010

Rees, W. E. (1996). Revisiting carrying capacity: Area-based indicators of sustainability. Population \& Environment, 17(3), 195-215. $\underline{\text { CrossRef }}$ 
Reill, P. H. (2010). Eighteenth-century uses of vitalism in constructing the human sciences. In D. R. Alexander \& R. L. Numbers (Eds.), Biology and ideology from Descartes to Dawkins (pp. 61-87). Chicago: University of Chicago Press.

Rockstrom, J., Steffen, W., Noone, K., Persson, A., Chapin, F. S., Lambin, E. F., ...Foley, J., (2009). A safe operating space for humanity. Nature, 461, 472-475. $\underline{\text { CrossRef }}$

Rosling, H. (2009). Hans Rosling: Let my dataset change your mindset [Video File]. Retrieved from: http://www.ted.com/talks/lang/eng/hans rosling at state.html on December 12, 2010

Simon, J. L. (1995). The State of Humanity: Steadily Improving. Cato Policy Report. Cato Institute. Retrieved from: http://www.webcitation.org/5Xu6Vhwdo on December 12, 2010

Smith, A. (1863). An inquiry into the nature and causes of the wealth of nations. London: T. Nelson and Sons.

Smith, A. (1976). The theory of moral sentiments. London: Oxford University Press.

Smith, A. (1978). Lectures on jurisprudence. Oxford: Oxford University Press.

Vermeij, G. J. (2004). Nature: an economic history. Princeton: Princeton University Press. 